\title{
非イオン性界面活性剤ベシクルの開発とDDSへの利用
}

\author{
加藤敬一 \\ 愛媛大学 大学院理工学研究科 物質生命工学・応用化学コース \\ 干 790-8577 愛媛県松山市文京町 3
}

\section{Development of Surfactant Vesicle and Application of the Vesicle to DDS}

\author{
Keiichi Kato \\ Department of Materials Science and Biotechnology, \\ Graduate School of Science and Engineering, Ehime University, \\ 3, Bunkyo-cho, Matsuyama 790-8577, Japan
}

\begin{abstract}
Nonionic surfactant Span80 was applied in the preparation of surfactant vesicle (niosome). We revealed that the membrane of Span80 vesicle was consisted of a mixture of sorbitan ester molecules with different four kinds of alkyl chains (1 4 chains). Furthermore, the ester composition in the membrane of the vesicles with constant diameter was found to be almost constant because the vesicle membrane was constructed by the thermodynamic self-assembly of the ester molecules. The comparision of the characterization between Span80 vesicles and conventional natural-lipid liposomes revealed that the Span80 vesicles had higher values in either fluidity or membrane fusion capability, and lower values in phase-transition temperature as compared with liposomes. The characteristics of Span80 vesicles were very effective in the application of Span80 vesicles to the drug delivery system (DDS). As a result, we could demonstrate the potential application of Span 80 vesicles from the experiments in vitro and in vivo as alternatives to conventional liposomes in DDS.
\end{abstract}

Key words : Span80 / niosome / vesicle $/$ liposome $/$ membrane stress $/$ DDS

\section{1. はじめに}

松本ら 1) は，非イオン性の界面活性剂 Span80（ソ ルビタンモノオリエート）がリポソームのような小 胞体構造を形成することを発見した。この発見をべ ースとして，筆者らは非イオン性の界面活性剂 Span80（ソルビタンモノオリエートとして市販）を 主成分とする，ハイブリッド型でナノサイズからマ イクロサイズのベシクルの開発に成功し，生体内や 血中におけるべシクルの安定化を実現するとともに,

Tel : 089-927-9928

Fax : 089-927-9928

E-mail : kato@eng.ehime-u.ac.jp
その膜構造を明らかにした。このベシクルは人工細 胞モデルとして知られる従来のリポソームと似て非 なるものであり, Span 80 膜で囲まれた小胞体構造を 有している。，一般に非イオン性界面活性剂（nonionic surfactant）によるベシクルはニオソーム（niosome） とも呼ばれている ${ }^{2,3}$. こ このベシクルの表面に癌細胞 へのミサイル装置としてのタンパク質や抗体などの 生理活性物質を固定化して癌細胞を標的・攻撃する 方法, あるいは遺伝子を固定化して遺伝子導入する 方法を開発した。筆者らのその後の研究で, この Span80を主成分とするベシクルが, 従来のリポソー ムにはない, 優れた流動性, 膜融合性などを有する ことを明らかにした．市販のSpan80は商品名がモノ オリエートとなっており, 1本鎖のエステルのみを有 


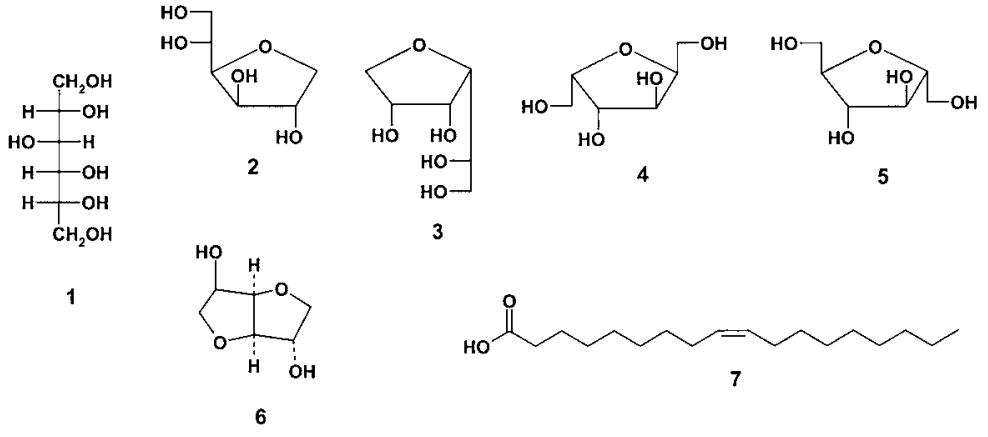

Fig. 1 Chemical structures of sorbitol (= D-glucitol, 1) and the products that can be formed upon acid treatment of sorbitol: 1,4-anhydro-D-glucitol (2), 3,6-anhydro-D-glucitol (3), 2,5-anhydro-L-iditol (4), 2,5-anhydro-D-mannitol (5), 1,4: 3,6dianhydro-D-glucitol (6). The chemical structure of oleic acid (7) is also shown. Commercially available sorbitan esters like Span80 or Span85 are non-ionic surfactants prepared from sorbitol. They, however, do not contain sorbitol as the central polyol but rather mixtures of sorbitol that has been anhydrized to various degrees.

するように思われがちであるが，実際には 1 本， 2 本， 3 本， 4 本のアルキルエステル鎖を有する脂肪酸エス テルの複雑な混合物から成っている。しかし, Span80から調製したベシクルは，それらエステル混 合物の一定組成で構成されることが明らかになった. また，Span80は非常に安価で食品添加物として国内 で認可されており ${ }^{4}$ ，その安全性については筆者らの 行ったマウス実験でも証明された。 また, Span80の 人体への投与例も既にあり ${ }^{5)}, S p a n 80$ ベシクルの人 体への投与が可能である.

本稿では, Span80ベシクルの調製法, そのベシク ル構造, ベシクルの特徵などについて述べる.さら に，筆者らが開発したSpan80ベシクルを癌細胞に標 的・結合させて，メンブレンストレスとしてのアポ トーシスシグナルを伝達させて癌細胞を殺傷させる Drug Delivery System（DDS）のメカニズムについて 紹介するとともに，抗体を固定化したイムノベシク ルや遺伝子ベクターとしての Span80ベシクルの利用 方法についても述べる.

\section{Span80ベシクルの調製法}

これまでに筆者らは，二段階乳化法 6,7$)$ により調製 した，Span 80 を主成分とする直径約 $1 \sim 10 \mu \mathrm{m}$ 大粒 径ベシクル ${ }^{6 \sim 10)}$, あるいは約 $10 \sim 300 \mathrm{~nm}$ の小粒径 ベシクル 11,12) について数多くの研究を行ってきた. これらの研究で用いたSpan80ベシクルの調製法は, 利用目的によっていくらか異なるが，基本原理は全 て以下に述べるようなものである $6,7,11$.
Span80を溶解したへキサン中に, 内水相 となる水滴を滴下しながらホモミキサーで 乳化 (一次乳化) して, W/O エマルション を調製する. その後, エバポレーターでへ キサンを除去して W/L (water/lipid) エマ ルションを調製する．このW/Lエマルショ ンをTween80（ポリオキシエチレンソルビ タンモノオリエート) 水溶液で乳化して (二次乳化), ベシクル懸濁液を調製する. このTween80はW/Lエマルションの分散剤 として用いるものである. 二次乳化後, こ の懸濁液に遠心操作, 透析あるいは限外濾 過などの処理を行うことにより, 膜形成し なかったSpan80成分やTween80を除去し て, 最終的に Span80ベシクル懸濁液を調製 する.このべシクル懸濁液には，大まかに 分類して大粒径ベシクル $(1 \sim 10 \mu \mathrm{m})$ と 小粒径ベシクル（10～300 nm）が混在して いる.これらのベシクルは限外濾過法や超 遠心分離法などで分別することができる.また，エ クストルージョン法で粒径を制御することも可能で ある.

なお, HPLCによるSpan80ベシクルの膜構造解析 実験においては, 解析を単純化するため, Span80単 一成分でベシクルを調製した。 しかし, 実際の利用 を目的としたSpan80ベシクルの調製では, 上記の一 次乳化時に, 主成分の Span 80 に対して, 若干の大豆 レシチン (Span80に対して $9.0 \mathrm{wt} \%)$ ，コレステロー ル（Span80に対して $4.5 \mathrm{wt} \%$ ）をへキサン中に配合 した. それにより, Span80単一成分のベシクルより もさらに安定性に優れた，ハイブリッド型のSpan 80 ベシクルを調製することができた.

\section{Span80ベシクルの形状と構造}

\section{1 市販の Span80 の組成}

Span80 は Fig. 1に示すような種々の構造を有する 混合物からなる非イオン性の界面活性剤で, グルコ ースを還元して得られる d-ソルビトールの脂肪酸エ ステルであり, 常温では油性の均一な液状である. Span 80 の成分は, 大別して 1 本鎖 $~ 4$ 本鎖のソルビ タンエステル成分からなり, さらに 1 本鎖, 2 本鎖エ ステルについては, ソルビット型（1個のエーテル環 を有する）とソルバイト型（2個のエーテル環を有す る）が含まれる事が知られている $4,13 \sim 15)$. 筆者らは, この均一系 $\operatorname{Span} 80$ （和光純薬製, 試薬特級）を, HPLCを用いて組成解析した. 
Table 1 Comparison of the compositions of sorbitan esters between commercial surfactants (Span80, Span85) and the vesicle membranes prepared from the surfactants

\begin{tabular}{ccccc}
\hline & \multicolumn{4}{c}{ Monoester(\%) } \\
\hline Commercial Span80 & 19 & 49 & 19 & 13 \\
Commercial Span85 & 6 & 26 & 15 & 53 \\
Span80 vesicle & 13 & 61 & 17 & 9 \\
Span85 vesicle & 16 & 60 & 17 & 7 \\
\hline
\end{tabular}

\subsection{Span80ベシクルの組成分析}

Span80ベシクルは，天然リン脂質を主成分とする リポソームと比較して, 前述のように多くの優れた 特性を有している。 しかし，そのベシクルの膜組成 や膜構造については，これまで不明な点が多かった。 我々は, 市販のSpan80 (均一系), およびSpan80か ら調製したべシクルを，HPLCを用いて分析し， Span80ベシクル膜の組成・構造の解析を試みた。こ こでは，それらの結果 $\left.{ }^{11} 116\right)$ の一部を紹介する.

結果の図は省略するが，市販の Span80では，大別 して4本のピークから成り, ソルビタンのモノ, ジ-, トリ-, テトラ-のエステル混合物で構成されているこ とが確認され，これらのエステル分子組成はそれぞ れ約 19，49，19，13\%となった。なお，この組成は Span80 の製品ロット番号で若干異なる．ここで使用 したもののロット番号は TCJ1112（和光純薬製）で ある。一方, Span80ベシクルに関しても同様に 4 本 のピークが現れ，ベシクル膜もまた，上記の 4 種類の エステル分子で構成されていることがわかった ${ }^{16)}$. さらに，市販のSpan85 および，Span85ベシクル系に ついても，同様に組成の解析を行った。 Span85は, エステル含有物は Span80 と同じであるが，テトラエ ステルが主成分であり, 商標ではソルビタントリエ ステルとして市販されている。上記の解析結果を Table 1に示す．その表に示すように，出発原料であ るSpan80 とSpan85の組成が異なっていても，それ らから調製した Span80ベシクルとSpan85ベシクル では, ソルビタンのモノ-, ジ-, トリ-, テトラ-の エステルの分子組成は，ほぼ同じになった。またべ シクルでは 2 本鎖と 3 本鎖のエステル分子が全体の約 80\%を占めた. このことは, ベシクルを形成すると, 1本鎖， 4 本鎖エステル分子が原料組成よりも減少し て，特に 2 本鎖が増加することがわかる．これらの結 果から，「ベシクルの原料となるソルビタンエステル の組成が異なっても, ベシクルは熱力学的に自己組 織化して生成され，2本鎖エステルを主成分とする一 定の膜組成を形成する」事実が明らかになった ${ }^{16)}$. 一般に, 薬剤は均一製品が要求されるが,この

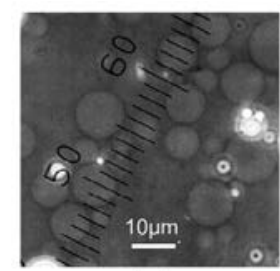

(a)

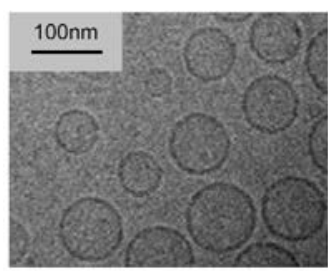

(c)

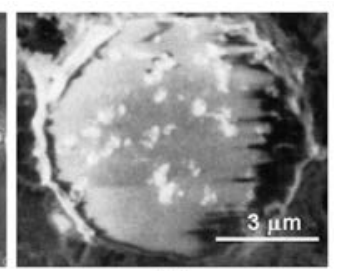

(b)

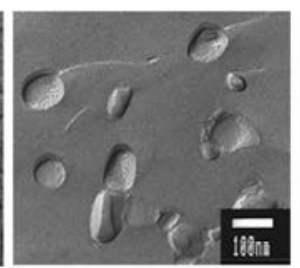

(d)
Fig. 2 Various electron microscopies of Span 80 vesicles prepared by two-step emulsification technique: (a) phase-contrast microscope, (b) SEM, (c) cryo-TEM, (d) TEM with freeze fracture method.

Span80ベシクル膜のエステル分子組成が一定になる という新しい発見は，このベシクルが，その薬剤に 利用できることを意味するものである．なお，筆者 らは 2 本鎖エステル分子を多く含有する Span 80 をべ シクル調製原料として用いた。

\subsection{Span80ベシクルの膜構造 ${ }^{11,16}$}

上記の結果から, ベシクルはハイブリッドな膜構 造をとることによって, 自己組織化して, 安定化し ていると推測される. 非イオン性のSpan80は, リポ ソームにおけるイオン性のリン脂質などと比較して, 親水部のソルビタン間の相互作用が弱い，そのため ベシクル膜中の Span80の分子運動の自由度はリポソ 一ムのそれよりも大きいと考えられる. また，モノ エステル〜テトラエステルまでの種々のエステル成 分が, Span80ベシクルの二分子膜の内膜と外膜のそ れぞれ異なる曲率を補うように細密充填的に自己組 織化され，安定な膜を形成すると考えている ${ }^{16)}$. な お, 二次乳化時に使用する Tween80 は, 非常に親水 性が高い（HLB 值は約 15.0）ため，ベシクル調製の 最終段階での透析操作時にほとんど系外に除去さ れる。

Fig. 2 にSpan80ベシクルの種々の電子顕微鏡写真 を示す．これらの写真から，このSpan80ベシクルが リポソームのような, きれいな小胞体構造を有して いることがわかる. ハンディ型のミニエクストルダ ー (Avanti PolarLipids, Alabaster, AL: ポリカーボネー 卜膜で細孔経 $100 \mathrm{~nm}$ ）を使用して, 粒径制御すると, 粒径が約 $100 \mathrm{~nm}$ 前後のベシクルが生成した. Fig. 2 
Table 2 Comparison of either $1 / \mathrm{P}$ values or phase transition temperatures $\left(\mathrm{T}_{\mathrm{m}}\right.$ 's) among commercial Span80, Span80 vesicle, and POPC, DOPC and DPPC lipsomes

\begin{tabular}{|c|c|c|c|}
\hline \multirow{3}{*}{ Sample } & \multicolumn{2}{|c|}{$1 / \mathrm{P}$} & $T_{m}$ \\
\hline & \multicolumn{2}{|c|}{$[-]$} & {$\left[{ }^{\circ} \mathrm{C}\right]$} \\
\hline & $20^{\circ} \mathrm{C}$ & $40^{\circ} \mathrm{C}$ & \\
\hline Commercial Span80 & - & - & $-20.3 \pm 3.2(\mathrm{n}=2)$ \\
\hline Span80 vesicle & 10.8 & 18.3 & $-40.3 \pm 2.6\left(n^{-4}\right)$ \\
\hline DOPC liposome & 9.98 & 15.6 & $-17.5 \pm 1.2(\mathrm{n}=4)$ \\
\hline POPC liposome & 7.81 & 13.9 & $-2.6 \pm 2.1 \quad(n=3)$ \\
\hline DPPC liposome & 3.14 & 3.31 & $42.2 \pm 2.6(n=4)$ \\
\hline
\end{tabular}

（a)，（b）に示すべシクルは上記のエクストルダーを 使用しないで調製したマイクロサイズのベシクルで

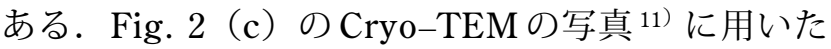
Span80ベシクルは，上記のエクストルダーを使用し て調製したもので，このCryo-TEM写真からの直接 測定した粒径は $63 \pm 21 \mathrm{~nm}$ となった（207個のベシ クルを数えた)。一方，DLSによる粒径測定では，約 $105 \pm 13 \mathrm{~nm}$ （測定回数： $\mathrm{n}=9$ ）となった. この粒 径の違いは, DLS 測定が間接的な測定法であり，水 和半径なども含むためと考えている．また，CryoTEM 写真の結果, Span 80 ベシクルの膜厚が約 $4.8 \pm$ $0.8 \mathrm{~nm}(\mathrm{n}=207)$ となり, POPCリポソームについて 同様に計算した結果である $4.8 \pm 0.9 \mathrm{~nm}$ の值とほぼ一 致した ${ }^{11)}$ 。このことは, Span80ベシクル膜が, リポ ソームのようなエステル分子混合物の二分子膜構造 を有していることを示唆している. また上記の写真 測定の結果から, Span 80 ベシクルの約 $84 \%$ が一枚膜 構造で, 残りが二枚膜ラメラ構造を有していた.

\section{Span80 ベシクルの特性}

Fig. 2 (a), (c) に示すように, Span80ベシクルは, 大粒径の場合（a）でも小粒径の場合（c）でもきれ いな球形をしている. また，このベシクルは，その 形状を自由に変化させることができ, マイクロサイ ズの大粒径ベシクルでも狭い毛細血管中を栓塞する ことなく自由に流動できることが，顕微鏡観察で確 認されている ${ }^{10)}$. また, 大きな内水相容積を有し, 遺伝子などのマクロ分子も包括可能である. さらに, ベシクル調製法が二段階乳化法であるため, ベシク ルの内水相溶液と外水相溶液とを，それぞれ異なっ た水溶液で構成させることができる．親水性の物質 はベシクルの内水相中に, また疎水性の物質は油性 のベシクル膜中にそれぞれ包括できる．例えば，筆 者らの実験で, 疎水性の非常に大きい抗癌剤ドセタ キセル（商品名タキソテール, TXT）も, 高い内包 率でこのベシクル膜中に内包することができた．ま

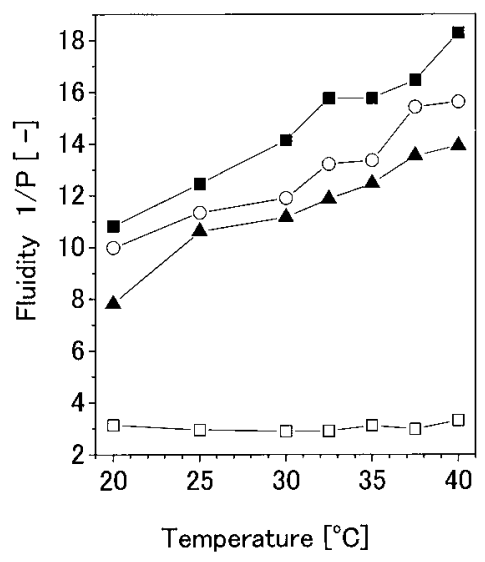

Fig. 3 Membrane fluidity measurements carried out with DPH. The inverse of the degree of polarization $(1 / \mathrm{P})$ is plotted as a function of temperature for Span 80 vesicles $(100 \mathrm{~nm})$

(匹), DOPC liposomes $(\bigcirc)$, POPC liposomes

$(\boldsymbol{\Delta})$ and DPPC liposomes $(\square)$. The phospholipid liposomes were prepared by PBS. The solid lines between the data point are drawn to guide the eyes.

た親水性の抗癌剤である 5-フルオロウラシル (5-FU) も TXT と同時にベシクルの内水相に包括され, かつ 安定であることもわかっている。この様に, Span 80 ベシクルはリポソームにはない多くの優れた特性を 有しており, 抗癌剂や遺伝子など様々な生理活性物 質が包括可能である.

\section{1 相転移温度}

比較するためのリポソームは, リン脂質である, POPC（1-パルミトイル-2-オレイル-sn-グリセロ -3-ホスホコリン, $\mathrm{Mw}=760.1), \mathrm{DOPC}(1,2-$ ジオレ イル-sn-グリセロ-3-ホスホコリン, $\mathrm{Mw}=786.2)$, DPPC（L- $\alpha$-ジパルミトイルホファチジルコリン, $\mathrm{Mw}=734.0 ）$ を用いて，エクストルダー法あるいは 逆相蒸発法によりそれぞれ調製した。これらのリン 脂質リポソームの相転移温度を Table 2 に示す ${ }^{11}$. ま た, 市販のSpan80 およびSpan80ベシクルの相転移 温度についても Table 2 に示した. 前述したように Span80ベシクルの組成は, 原料となる Span 80 の組成 とは異なる，その組成の違いが，市販の Span 80 と Span80ベシクルとの相転移温度が異なる原因の一つ と考えられる. Table 2から, Span80ベシクルの相転 移温度の方が, リン脂質リポソームのそれよりも低 いことがわかる。このことは, 室温あるいは $40{ }^{\circ} \mathrm{C}$ (生体温度近傍) では, Span80ベシクルの方がより液 晶状態が進んだ状態にあると言える。そのことが, Span80ベシクルが, これらのリポソームよりもより 

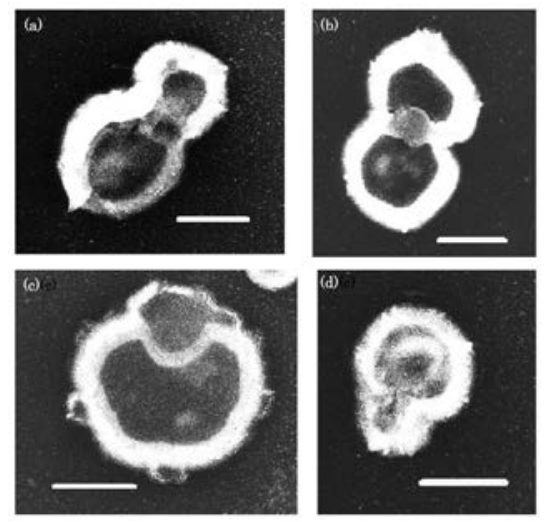

Fig. 4 Negative staining electron micrographs of various fusion Span80 vesicles $(100 \mathrm{~nm})$ which were stored for 3 days at $42^{\circ} \mathrm{C}$ before they were analyzed by electron microscopy. Length of the bar: $300 \mathrm{~nm}$.

流動性が高くなる要因の一つであると言える.

\section{2 膜流動性}

Span80ベシクルと種々のリン脂質リポソームの膜 流動性を，疎水性蛍光プローブ (1,6-diphenyl-1,3, 5-hexatriene, DPH (和光純薬製)）を用いて測定した 蛍光偏向度 $\mathrm{P}$ 值 ${ }^{17,18)}$ の逆数から評価した結果を Fig. 3 に示す ${ }^{11)}$. Span80ベシクルの $1 / \mathrm{P}$ 值は, POPC, DOPC，DPPCのいずれのリポソームの $1 / \mathrm{P}$ 值よりも 高い值となり, Span80ベシクルが, これらのリポソ 一ムよりも流動性に優れていることが判明した ${ }^{11,18)}$. この原因としては, 前述したように1）Span80ベシ クルの相転移温度が低いこと，2）Span80の成分であ るソルビタンエステルの親水性の部分が中性であり イオン間相互作用がないこと，3）多種の分子が自己 組織化して膜を形成していること，などが考えられ る. Table 2 にこれらの膜流動性の結果も前述の相転 移温度の結果と比較して記したが，これらの流動性 は相転移温度が低いほど高くなっていることがわか る. DDSの薬物キャリアとしてべシクルを利用する 場合，このような Span80ベシクルの優れた膜流動特 性は, 生体での血管内流動, 血管内皮細胞中の移動, 癌細胞近傍の血管壁細孔のベシクルの通過，あるい はベシクルー癌細胞間の膜融合などで大きな利点とな ると考えられる ${ }^{19}$.

\section{3 膜融合}

Span80ベシクルの高い膜融合性は，筆者らのこれ までの実験からもある程度わかっていたが, 電子顕 微鏡（ネガティブ染色法）により, さらに詳しく, ベシクルーベシクル間の膜融合を観察した。 その結果 を Fig. 4に示すが, ベシクルの融合が生じていること

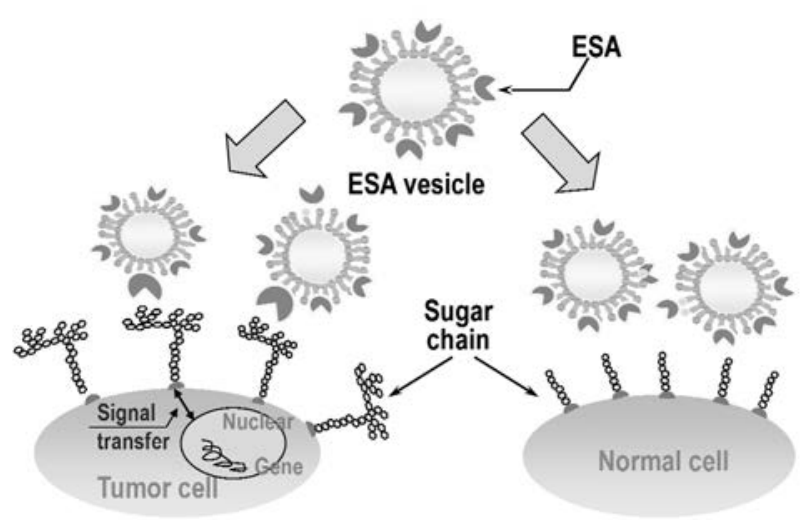

Fig. 5 The schematic scheme of the specific combining of ESA-immobilized vesicles with tumor cell by recognizing the special sugar chain on the surface of a tumor cell.

がわかる $\left(42^{\circ} \mathrm{C}\right)$ ．このような融合は，インキュベー 卜温度が $-4{ }^{\circ} \mathrm{C}, 25^{\circ} \mathrm{C}$ では観察されなかった. またこ の融合は温度に対して不可逆であった。 なお, リポ ソームでは, このような融合は観察されなかっ た ${ }^{11)}$ 。この高い膜融合は, in vitroでのべシクルー細 胞間で室温でも観察された ${ }^{8)}$. この膜融合性は Span80ベシクルの低い相転移温度のみが原因でなく, Span80の親水基の部分の温度上昇に伴う脱水和にも 起因していると考えている ${ }^{11)}$.

\section{Span80ベシクルの癌治療 DDSへの利用}

\subsection{DDS における Span80ベシクルの利用}

筆者らは, これまでに $\mathrm{Span} 80$ ベシクルの多くの利 用について検討してきた $7,20,21)$ が，本章ではDDSに おける利用を中心として, いくつか代表例を解説 する.

ミサイル攻撃的に薬物封入 $\mathrm{Span} 80$ ベシクルを誘導 して，そのベシクル中の抗癌剤や遺伝子などを目的 細胞に集中的に導入することが可能となれば, 癌治 療, 遺伝子治療などの分野で大きな成果が予測でき, 実用化が期待される。このような手法は一般にDrug Delivery System（DDS）と称されている.

筆者らは, このSpan80ベシクルを癌治療や遺伝子 治療のためのDDSに利用することを着想した。 Span80ベシクルを癌治療のDDSにおける薬物キャリ アとして人体に投与する場合, 血中でのベシクル安 定性, 血管壁のベシクル透過性, 癌細胞へのベシク ル融合などの点で多くの利点を有している ${ }^{19)}$. さら に, Span80 は天然リン脂質に比べはるかに安価であ り, また食品添加剤として認可されており, 人体へ の注射投与例も既にある ${ }^{5)}$. そこで, Span80ベシク 


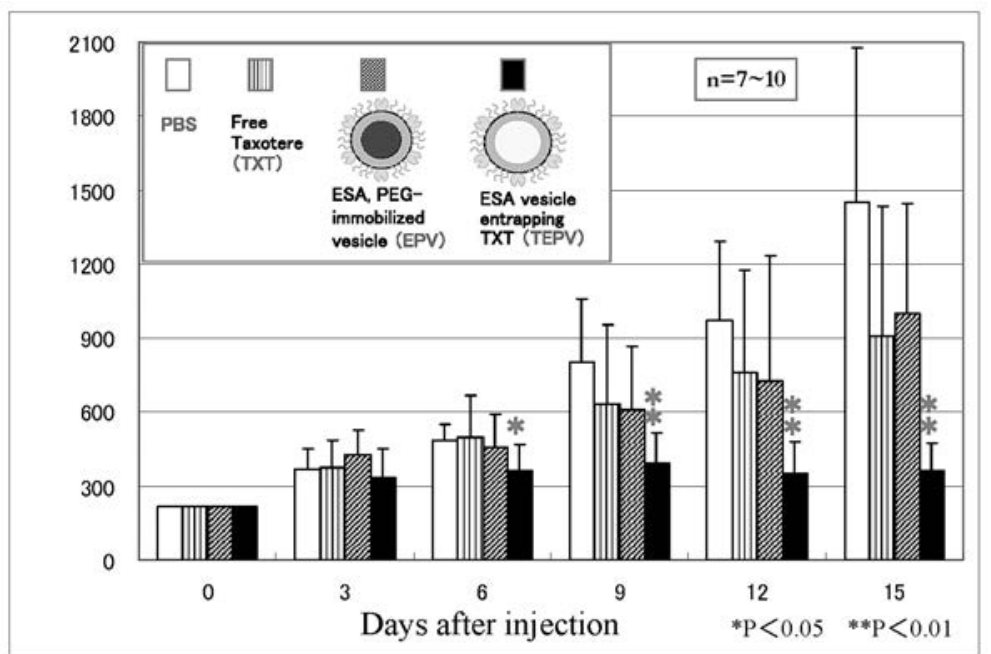

Fig. 6 Comparison of the antitumor activities of the injected samples in $\mathrm{BALB} / \mathrm{c}$ mice burden with Colon26 tumor (mouse colon-cancer cell-line). Samples $=$ PBS, docdetxel (antitumor agent: TXT), EPV (ESA-PEG Span80 vesicle immobilized with both ESA and PEG), and TEPV (EPV entrapped with TXT); the samples were injected by tail vein every three day; ESA concentrations $=\mathrm{EPV}$ $(1.5 \mathrm{mM})$, TEPV $(1.5 \mathrm{mM})$; TXT concentrations $=$ TXT $(0.7$ $\mathrm{mM})$, TEPV $(0.7 \mathrm{mM})$ : injected sample volume $=10 \mu \mathrm{l} / \mathrm{g}$ (mouse).

ルをDDSに利用できれば，これまでにない多くの利 点が得られると考えた。このような視点から， Span 80 ベシクル表面に, 癌細胞へのミサイル装置を 装着するアクティブターゲッティングを検討した. ここでは, 主に癌治療や遺伝子導入を目的として, 癌細胞表面の固有の分子を認識するリガンド，すな わち癌細胞への “ミサイル誘導装置”をそのべシク ルに装着（固定化）して, 癌細胞への標的機能を付 与する例を挙げる.

\section{2 癌細胞攻撃ミサイル装置としての ESA}

ミサイル装置として，抗体 22, 23) やレクチン 10) など のような特定の物質と特異的な結合親和性を持つ分 子を用いることにより, 以下に述べるようにべシク ルに標的指向性を付与することが可能となる．レク チンとは特定の糖鎖構造を認識して結合する糖結合 性タンパク質である。我々は癌細胞, 特に大腸癌細 胞と特異的に強い結合性を示す新規の海藻由来レク チンをミサイル装置として Span80ベシクル表面に固 定化し，そのべシクル膜内部には制癌剂のドセタキ セル（TXT）を包み込んだ Span80ベシクルを開発し た ${ }^{24)}$. 本研究で用いたレクチンESA (Euchuma Serra agglutinine）は海藻トゲキリンサイ由来の新規レクチ ンであり, 筆者らの共同研究グループが開発したも のである ${ }^{25)}$. ESA は分子量約 28000 の単純タンパク
質で, 複雑な枝分かれをしたハイマンノー ス構造を特異的に認識して結合する ${ }^{26)}$. 癌 細胞表面上の糖鎖構造は, 正常細胞の糖鎖 構造よりも非常に複雑化（ハイマンノース 化）していることが知られてい る ${ }^{27)}$. 本レクチンは癌細胞上のその複雑な 構造の糖鎖を特異的に認識することにより， 正常な細胞に対してよりも強い結合力で癌 細胞表面に結合する. さらに, ヒトの大腸 癌細胞, 子宮癌細胞, 肺癌細胞, 骨肉腫な ど, 多くの癌細胞に特異結合するばかりで なく, 癌細胞にアポトーシス ${ }^{28)}$ と呼ばれる 細胞死を誘導する効果があることも明らか となった ${ }^{26)}$.さらに動物実験レベルにおい てもレクチン自身の抗腫瘍効果が実証され た ${ }^{12)}$.

Fig. 5に模型図を示すが，このESAを癌 細胞への “ミサイル装置”として利用して, Span80ベシクル表面上に固定化し，その $\mathrm{ESA} \cdot \mathrm{PEG}$ 固定化ベシクル（PEGも同時に 固定化してマクロファージからの攻撃を回 避させた：以下EPV と略称）を癌細胞に対 して特異標的させ，さらには殺傷すること を試みた ${ }^{29,30)}$ 。ここで用いた EPVは，2 章で述べた ようにベシクルの安定性を強化するために, 若干の 大豆由来のレシチンとコレステロールを $\operatorname{Span} 80$ に混 合させた，いわゆるハイブリッド型の Span 80 ベシク ル（粒径が $100 〜 300 \mathrm{~nm}$ の範囲で使い分けた）で ある。

まず, Span80ベシクルに固定化した ESAが癌細胞 へのミサイル装置としての機能を果たすことを確認 するため, ESA固定化べシクル（PEGを固定化して いない：EVと略称）を用いて, in vitroで実験を行 った。種々の癌細胞抢よび正常細胞への EVの結合能 をフローサイトメーター（FACS）により測定して検 討した ${ }^{30)}$ 。なお, EV内部にはトレーサーとしての蛍 光物質を包括した. 用いた癌細胞は, HB4C5（リン パ腫由来), Colo201 (ヒト大腸癌細胞株), MCF7 （ヒト乳癌細胞株）などであり, 正常細胞として, 臍 帯由来繊維芽細胞 (Fibrobrast) や乳腺細胞 (MCF 10-2A）を用いた. その結果, この EVが正常細胞に はほとんど結合せず，癌細胞に対して特異結合する ことが明らかになった。 また，上記の癌細胞や正常 細胞に対して, ESAを固定化していないSpan80ベシ クルと $\mathrm{EV}$ の癌細胞増殖抑制能を, in vitroで比較検 討した ${ }^{30)}$.いずれも細胞培地に対して，1wt\%のベシ クルを添加した. Colo201, MCF7などの癌細胞に対 しては, EVの方が細胞増殖抑制効果が大きくなった. 


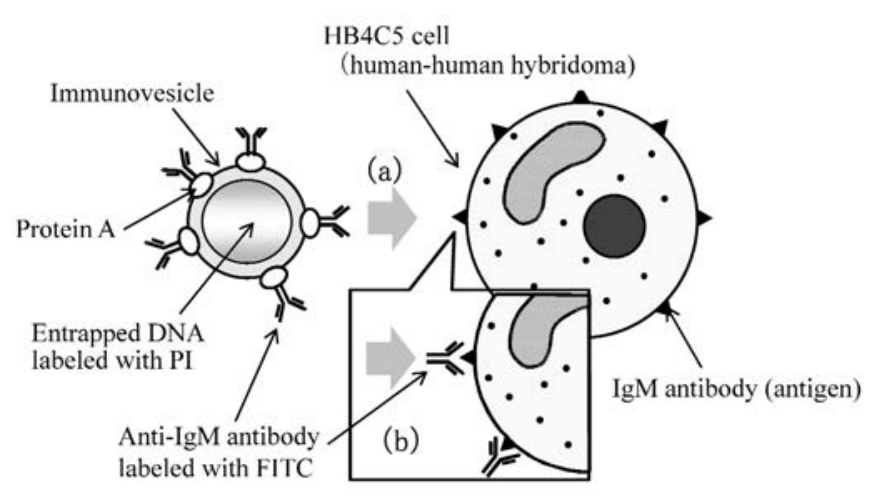

Fig. 7 Schematic scheme ${ }^{38)}$ of the experiments of the specific binding between immunovesicle and HB4C5 cell (human-human hybridoma): (a) non masking of the IgM on the cell; (b) masking of the IgM.

また，それらの細胞が，ベシクル投与後 1 日を経過す ると障害を受けていることも，顕微鏡観察により明 らかにし，この現象が固定化 ESAによる Caspase3 経 由のアポトーシス発現であることを確認した ${ }^{26)}$ 。一 方，正常細胞の Fibrobrastに対しては，そのような 細胞増殖抑制能や障害の影響は観察されなかった ${ }^{30}$. 特にヒト大腸癌細胞（Colo201）に対してその強い特 性を発現した。

そこで，EVにステルス機能を付与した EPVを用い て，マウスへの投与実験を行った抗癌活性発現の一 例を Fig. 6に示す．マウウスに移植した癌細胞は，マウ ス大腸癌細胞 Colon26である. 投与サンプルとして 以下の 4 種類のものを用い，それらを投与した場合の マウス癌細胞の体積の経日変化を表したものであ る12,31 35). サンプルは, PBS, フリーの抗癌剤ドセ タキセル (TXT), ESA・PEG 固定化ベシクル (EPV) および，TXT内包の EPV（TEPV）である. Fig. 6か らわかるように，抗癌剤TXTを内包したSpan80ベシ クル（TEPV）の投与の場合, マウス大腸癌細胞の増 殖をほぼ完全に抑制させることに成功した。また， 抗癌剤TXTを内包していない Span80ベシクル (EPV) を投与した場合でも，フリーのTXT投与の場合とほ ぼ同程度の抗癌活性を発現した. また，EPVの投与 により, 腫瘍組織の血管周辺の癌細胞にアポトーシ スによる細胞死誘導のメカニズムが働くことが明ら かとなった ${ }^{31,32,36)}$ 。さらに，このベシクルが血管壁 を通過して, 癌細胞を特異的に標的する体内動態な ども担癌マウスに対する放射性アイソトープ（RI） 実験で実証した $33,34,36$.

以上の結果から, Span80ベシクルに抗癌剂を内包 し, 癌細胞に対してミサイル効果を発揮する物質 （ここでは ESA）を膜表面に固定化することにより， 癌に対するDDSを構築することが可能であり，動物
実験レベルではあるが, 癌増殖抑制の治療効果が実 証された．また，ヒト大腸癌細胞（Colo201）を持つ 担癌マウスに対しても同様の結果が得られた。さら に，抗癌剤を使用することなく，このEPVをDDSに 用いることにより, 癌細胞を死滅させ, 癌治療に利 用できることも示すことができた.

\section{3 イムノベシクルの調製とその機能}

ここではミサイル物質として抗体を利用する場合 について述べる.このSpan80ベシクルの表面に抗体 を固定化して (イムノベシクル), 癌細胞表面の抗原 （その固定化抗体に対する）を狙い撃ちさせる，いわ ゆる癌細胞標的機能ベシクルの調製に成功し た $22,23,37$. このイムノベシクルの模型図を Fig. 7 に示 す ${ }^{38)}$. 使用例としてのモデル癌細胞は, ヒト-ヒト ハイブリドーマの HB4C5 細胞（肺癌患者由来のリン パ球とヒトリンパ腫細胞の掛け合わせ細胞）であり, この細胞はその表面に IgM 抗体を産生する。一方, 抗体（IgGモノクロナール抗体で，ここでは抗 IgM 抗体を使用）の $\mathrm{Fc}$ 部分と特異結合するプロテイン A を，予めべシクル表面に固定化した。 そのプロテイ ン Aを媒介させて, 抗 IgM抗体を姿勢制御した形で Span80ベシクル上に固定化した. なお, 癌細胞は一 般に負電荷を帯びているので, Span 80 ベシクルの癌 細胞への標的性を増すために, Span80 中に10〜 $20 \mathrm{wt} \%$ のカチオン性ペプチド脂質（ $N, N-$ ジへキサデ ル $-N^{\alpha}-[6-($ トリメチルアンモニウム) ヘキサノイ ル ]-L-アラニンアミドブロマイド : $N^{+} \mathrm{C}_{5} \mathrm{Ala} 2 \mathrm{C}_{16}$, CPL ${ }^{17)}$ と略称）を混合させた。

上記のイムノベシクルが， IgMの抗原（抗 IgM 抗 体の標的となる）を有する HB4C5 細胞にどのような 標的性を有するか検討した ${ }^{37}$. Fig. 7（a）および（b） は，それぞれ HB4C5上の IgMを，抗 IgM抗体で予め マスキングしない場合と，マスキングした場合の， イムノベシクルの結合の様子を示す模型図である. イムノベシクル内部には, 蛍光物質であるプロピデ イウムアイオダイド（PI）でラベルしたニシン精巣 由来の DNAを内包させ，その DNAのPIの蛍光をフ ローサイトメーター（FACS）で測定することにより， このイムノベシクルと HB4C5 細胞との結合能を調べ た．詳細は省略するが，マスキングしない（a）の場 合にはべシクルは HB4C5 細胞に結合するが，マスキ ングした（b）の場合にはほとんど結合しなかった. このことは, このイムノベシクルが HB4C5上の IgM 抗体を認識して, HB4C5に特異結合する機能を有し ていることを示している. また，ヒトリンパ球上の CD45 タンパク質 ${ }^{10)} や ， E R M 5-1$ 細胞 ${ }^{39)}$ 上の EGFR を抗原とする場合についても，これらの抗原に対す 
る抗体を固定化したイムノベシクルを用いて，それ らの細胞への標的機能を，上記と同様に発現させる ことに成功した。

以上述べてきたように，Span80ベシクル上に抗体 を固定化した，いわゆるイムノベシクルがその抗体 の抗原を有している細胞に対して特異的に結合し， ベシクルに内包したDNAを，その標的細胞内に導入 することができた。この導入効率はべシクル膜の膜 融合性によっても大きく左右されるものと予測され る. 先に述べた Span 80 ベシクル膜の高い融合性, 流 動性はin vivoの遺伝子導入に大きく寄与するものと 期待している.

\section{Spanベシクルによる遺伝子導入}

本章では, 我々の行った遺伝子ベクターとしての Span80ベシクル利用の基礎実験の結果について述べ る. ベシクルで遺伝子導入する場合, 導入する遺伝 子をベシクル内部に内包する内包ベシクルと, ベシ クル表面に遺伝子を多数結合させて遺伝子導入する 外付けベシクルの 2 通りの方法がある. ここでは, 外

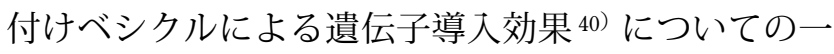
例を紹介する.

Span80にカチオニックペプチド脂質 CPLを混合さ せたナノサイズのプラスミド外付けベシクルを調製 した．このベシクルの遺伝子導入ベクターとしての 機能を，ヒト子宮癌細胞である Hela細胞を用いて検 討した.リポーター遺伝子としては, pcDNA3にル シフェラーゼ遺伝子を組み込んだ pcDNA3-luciを使 用した. Hela 細胞に遺伝子を導入後, その遺伝子発 現量をルミネッセンサーにより検出した．筆者らは， 遺伝子導入効率を上昇させるために遺伝子と Span 80 ベシクルの複合体の形成を促進するいくつかの処理 剤（プロタミン，ポリLリジン（PLL），ヒストン） を塩基性分子を中心に検討した，その結果，アミノ 酸の一種である PLLが有効であることが確認され 40) (実験結果は省略), PLLの遺伝子処理により, 遺伝 子導入効率は約 1,000 倍向上することがわかった. 遺 伝子導入にはべシクル膜の高い流動性と安定性が必 要となるが，前述のようにこのSpan80ベシクルはそ の条件を満たしており，市販のリポソームを用いた リポフェクタミン法に代わる遺伝子導入ベクターと して，今後の開発が期待される.

\section{7. おわりに}

Span80が複雑なエステル分子の混合物であるため, Span80ベシクル膜もまた組成がばらばらで, 医薬品
には不向きという意見もあった. しかし，筆者らは， そのSpan80ベシクル膜の構成がそのエステル分子の 熱力学的な自己組織化によるため, その膜の組成は 一定になることを発見した。.また, Span 80 ベシクル の高い膜流動性や膜融合性の故に，このベシクルが DDSの分野において有効である事もわかってきた. Span 80 の人体への注射投与は既に認可されており， 筆者らの行った Span80ベシクルのマウス体内での毒 性試験でも問題は見られなかった。こうして，従来 のリポソームに代わるSpan80ベシクルの臨床応用は 身近なところに来たように思われる。“ミサイル装置” としての生理活性物質を固定化したSpan80ベシクル を癌細胞に標的させ, 癌細胞膜上のレセプターを介 してメンブレンストレスとしてのアポトーシスシグ ナルを核に伝達させて癌細胞を殺傷する機能の付与, あるいは遺伝子導入機能の付与, などに関する新し い技術は，メンブレン・ストレスバイオテクノロジ 一分野に大きな貢献を果たせると信じる.

\section{謝辞}

本研究の一部は, 文部科学省科学研究費補助金, 地域連携推進研究 (No.11793066), 基盤研究 (B) (No.16360415), 科学技術振興機構 (JST) シーズ発 掘試験研究（平成 20 年度 A-1199）の援助を受けた. また, 本研究は下記の多くの研究者のご協力を得た プロジェクト研究として遂行することができた。こ こに深く謝意を表する：（スイス連邦工科大学 (ETH) ) Peter Walde教授；（愛媛大・医）宮崎龍彦 准教授; （東海大・医）山崎等准教授; （愛媛大・ 総研支援）藤原隆准教授, 増田晴造講師, 秋山浩一 助教, 首藤政親技術専門職員; (愛媛大・農) 菅原 卓也准教授；（筑波大院）市川創作准教授；（国立 四国がんセンター）佐伯俊昭臨床部長（現埼玉医大 教授), 青儀健二郎腫瘍外科主任研究員, 平家勇司主 任研究員；（ヤマキ(株)）稲田明宏研究開発所長. 最後に, メンブレン・ストレスバイオテクノロジー の研究会を通じて, 多くのご助言を頂いた大阪大学 大学院基礎工学研究科の久保井亮一教授, 馬越大准 教授, 島内寿徳助教に深謝の意を表す.

\section{文 献}

1) Matsumoto S, et al. : J. Colloid Interface Sci., 62, (1), 149157 (1977)

2) Florence AT : Liposome Technology; G. Gregoriadis Ed., CRC Press (Boca Raton), FL, 1, 157-176 (1993)

3) Uchegbu IF and Vyas SP : Int. J. Pharm., 172, 3370.(1998)

4) 藤本武彦：新・界面剂入門, 三洋化成工業（株）(1981)

5）粧原基：日本薬局方解説書, CAS, No.8007-43-0 
6) Kato K, Walde P, Mitsui $\mathrm{H}$ and Higashi $\mathrm{N}$ : Biotech. Bioeng., 84, 415-423 (2003)

7) Kato K, Ikeda T and Shinozaki M : J. Chem. Eng. of Japan, 26 (2), 212-216 (1993)

8) Kato K, Sugahara T et al. : Proc. of the $16^{\text {th }}$ meeting of European Society for Animal Cell Technology (ESACT) (Lugano), Kluwer Academic Publishers, 429-431 (1999)

9) Kato K, Sugahara T, et al. : Proc. of Biotechnology 2000 (Berlin), 79-81 (2000)

10) Kato K and Hirashita J : Proc. of the $4^{\text {th }}$ APBioChEC'94 (Beijin), 592-596 (1997)

11) Kato $K$, Walde $P$, Koine $N$, Ichikawa $S$, et al. : Langmuir 2008, 24, 10762-10770 (2008)

12) Fukuda Y, Sugahara T, et al. : Anti-Cancer Drugs, 17, 943947 (2006)

13) Lewis JL : Nonionic Surfactants; Organic Chemistry, van Os, NM, Ed., Marcel Dekker Inc: New York, Surf. Sci. Ser. 72, pp.201-240 (1998)

14) Wang $Z$ and Fingas $M$ : HRC-J. High Res. Chrom., 17, 1519 (1994)

15) Bock K, Pedersen C and Thogersen H : Acta Chem. Scand. B, 35, 441-449 (1981)

16) Kato K, Walde P, et al. : J. Disp. Sci. Technol., 27 (8), :1217-1222 (2006)

17) 村上幸人編：超分子化学の基礎と応用 ; 蛍光プローブ による反応場の評価 (横野照尚), エヌ・ティー・エス, 566-570 (1996)

18) 重川庸介, 加藤敬一, 戸澗一孔, 佐藤玲子, 河本 涼, 太田 多寿, 辻井哲也：Membrane, 32(5) , 302-310 (2007)

19) 重川庸介：大腸がん標的攻撃機能を有する新規レクチ ン固定化界面活性剂ベシクルの開発と機能解析. 愛媛大 学博士論文 (2008)

20) Kato K and Hirata K : Solv. Extr. Res. Dev. Japan, 3, 62-73 (1996)

21) Kato K, Tsutanaga A and Shinozaki M : Solv. Extr. Res. Dev. Japan, 4, 51-61 (1997)

22) Sugahara T, Kawashima S, Kato K, et al. : Cytotechnology, 47, 51-57 (2005)

23) Kato K, Sugahara T, et al. : Proc. of the $16^{\text {th }}$ meeting of European Society for Animal Cell Technology (ESACT) (Lugano), Kluwer Academic Publishers, $433-435$ (1999)

24) 小林 猛編：“バイオターゲティングのための生体分 子デザイン”, 文部省科学研究費「特定領域研究」成果 報告書 (1999)

25) Kawakubo A, et al. : J. Appl. Physiol, 9, 331-338 (1997)

26) Sugahara T, Kato K, et al. : Cytotechnology, 36, 93-99 (2001)

27) 日経バイオテク：日経バイオテク最新用語辞典, 日経 BP社 (1995)

28) 米原 伸編：アポトーシス研究の新展開, 現代化学増 刊 35, 東京化学同人 (1997)

29) 加藤敬一：BIOINDUSTRY, シーエムシー, 15 (15), 1118 (1998)
30) 加藤敬一, 菅原卓也, 川久保明宏ら: 化学工学シンポジウ ムシリーズ, 76, 230-238（2001）

31) Kato K, Walde P, et al. : Proc. of $11^{\text {th }}$ Liposome Research Days Conference, P43, 168 (2008)

32) Kato K, Walde P, et al. : Proc. of International Scientific Seminar "Sience and Engineering of Biomembrane and Its Mimics” : Japan/Switzerland, 27-28 (2008)

33) Kato K, Omokawa Y, Akiyama K, et al. : Proc. of $6^{\text {th }}$ European Symposium on Biochemical Engineering Science (ESBES 6), in Salzburg/Austria (2006)

34) Kato K, Fukuta Y, Fukuda Y, et al. : Proc. of $6^{\text {th }}$ European Symposium on Biochemical Engineering Science (ESBES 6), in Salzburg/Austria (2006)

35) Kato K, Omokawa Y, Fukuda Y, Sugahara T, et al. : Proc. of the $4^{\text {th }}$ Symposium on Engineering Science of Liposome, Zurich (2006)

36) Kato K, Omokawa Y, et al. : Proc. of the $10^{\text {th }}$ Asian Pacific Confederatio of Chem. Eng. (APCChE), Vol. 2004, No. SPACE pp.500- (2004)

37) 加藤敬一, 川嶋真一, 菅原卓也 : ケミカルエンジニアリ ング, 45(6), 49-55 (2000)

38) 秋吉一成・辻井 薰 監修: リポソームの応用の新展 開 - 人工細胞の開発に向けて - ; 非イオン界面活性剂 Span80の構造と利用 (加藤敬一), エヌ・ティー・エス, 第 8 章, 407-414 (2005)

39) Kato K, Manabe T, et al. : Proc. of the $10^{\text {th }}$ Asian Pacific Confederatio of Chem. Eng. (APCChE) Vol. 2004, No. SPACE pp.501- (2004)

40) Ohama Y, Heike Y, Sugahara T, et al. : Biosci. Biotechnol. Biochem. 69 (8), 1453-1458 (2005)

(Received 15 October 2008; Accepted 17 October 2008)

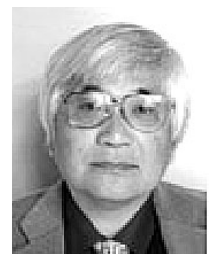

\section{著者略歴}

加藤 敬一（かとう・けいいち）

1975年 3 月 九州大学大学院工学研 究科化学機械工学専攻 博士課程単位修得退学

1977年 12 月 工学博士

1977年 4 月 九州大学工学部 助手

1982 年 3 月 愛媛大学工学部資源化 学科 助教授

1999年 文部省在外研究員とし て，スイス連邦工科大 学およびマンチェスタ 一工科大学に留学

2007 年 4 月 愛媛大学大学院理工学 研究科物質生命工学専 攻 准教授 